\begin{tabular}{|c|c|c|c|}
\hline $\begin{array}{c}\text { Case Reports in } \\
\text { Oidu: }\end{array}$ & \begin{tabular}{|l} 
Case Rep Oncol 2011;4:82-87 \\
DOI: $10.1159 / 000324581$
\end{tabular} & \begin{tabular}{|l} 
Published online: \\
February 16, 2011
\end{tabular} & \begin{tabular}{|l} 
O 2011 S. Karger AG, Basel \\
ISSN 1662-6575 \\
www.karger.com/cro
\end{tabular} \\
\hline
\end{tabular}

\title{
Gemcitabine Monotherapy Associated with Posterior Reversible Encephalopathy Syndrome
}

\author{
Luiz Carlos Porcello Marrone ${ }^{a, b, d}$ Bianca Fontana Marrone ${ }^{e}$ \\ Julia de la Puerta Raya ${ }^{d}$ Giovani Gadonski ${ }^{b, d}$ \\ Jaderson Costa da Costa ${ }^{a, c, d}$

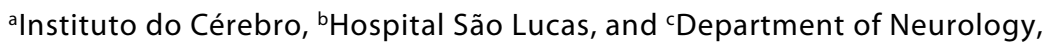 \\ Faculdade de Medicina, all at dPontifíciae Universidade Católica do Rio Grande \\ do Sul, and eDepartment of Oncology, Hospital de Clínicas de Porto Alegre, \\ Porto Alegre, Brazil
}

\section{Key Words}

Posterior reversible encephalopathy syndrome $\cdot$ Gemcitabine $\cdot$ Chemotherapy

\begin{abstract}
Posterior reversible encephalopathy syndrome is a clinicoradiologic entity that may present with headaches, altered mental status, seizures and visual loss as well as specific neuroimaging findings. We report a case of a 74-year-old woman receiving adjuvant gemcitabine chemotherapy as monotherapy for a stage lla pancreatic adenocarcinoma, who developed posterior reversible encephalopathy syndrome.
\end{abstract}

\section{Introduction}

Posterior reversible encephalopathy syndrome (PRES) is a clinicoradiologic entity characterized by headaches, altered mental status, seizures, and visual loss and is associated with white matter vasogenic edema predominantly affecting the posterior occipital and parietal lobes of the brain [1-6].

The pathophysiology of PRES remains unclear. Two pathophysiologic mechanisms have been proposed regarding cerebral autoregulation: cerebral vasospasm, which results in cytotoxic edema $[7,8]$, and vasodilatation, which results in vasogenic edema $[3,9,10]$. The latter is more favored by most experimental and clinical data [11-15]. The pathophysiology of PRES also implicates endothelial dysfunctions, such as preeclampsia or cytotoxic therapies, especially in cases without severe hypertension $[1,16,17]$. 
Numerous factors can trigger this syndrome, the most common being acute elevation of blood pressure, abnormal renal function and immunosuppressive therapy [1]. Other possible etiologies are eclampsia [7, 18-21], lupus [22, 23], transplantation [24], neoplasia and chemotherapy treatment [25], systemic infections [26], and acute or chronic renal disease $[27,28]$.

Gemcitabine has been associated with PRES; nevertheless, the contributory effects of other drugs administered simultaneously with or previously to gemcitabine are not well clarified [29]. The purpose of this report is to present a case treated with gemcitabine as monotherapy.

\section{Case Report}

A 74-year-old woman was diagnosed with pancreatic cancer without evidence of metastasis. She underwent pancreaticoduodenectomy, which revealed no regional lymph node metastases or microscopic residual disease (T3 N0 M0). After 4 weeks, the patient was started on her first course of adjuvant treatment with gemcitabine $\left(1,000 \mathrm{mg} / \mathrm{m}^{2}\right.$ on days 1,8 and 15 of each 28 -day cycle). Her ECOG performance status was 1 .

One day after the beginning of the third chemotherapy cycle, the patient developed severe headache. After a few hours, she experienced a tonic-clonic seizure and visual blurring. At that time, her blood pressure was 170/90 $\mathrm{mm} \mathrm{Hg}$ and her creatinine level was $1.4 \mathrm{mg} / \mathrm{dl}$ (2 months before, it was $1.0 \mathrm{mg} / \mathrm{dl})$. A head computed tomography was obtained, which showed mild focal hypodensity in both occipital lobes without any evidence of brain metastasis. In addition, a brain magnetic resonance imaging (MRI; $\mathrm{T} 2$ and fluid-attenuated inversion recovery image sequences) was performed, which revealed a subcortical T2 hyperintensity without enhancement, apparent on both the occipital and temporal lobes (fig. 1).

The patient was treated with phenytoin and had no further seizures. After 10 days, the patient was asymptomatic and after 2 weeks, she underwent a follow-up brain MRI, which showed no cortical or subcortical T2 hyperintensity (ig. 2).

\section{Discussion}

The cause of PRES is not yet understood. Hypertension with failed autoregulation and hyperperfusion remains a popular consideration for developing brain edema [1]. The suggested pathophysiologic mechanisms are cerebral vasospasm with resulting ischemia within the involved territories and a breakdown in cerebrovascular autoregulation with ensuing interstitial extravasation of fluid [8].

The most characteristic imaging pattern in PRES is the presence of an edema involving the white matter of the posterior portions of both cerebral hemispheres, especially the parieto-occipital regions, in a relatively symmetric pattern that spares the calcarine and paramedian parts of the occipital lobes [1, 3, 30,31]. However, other structures such as the brain stem, cerebellum, and frontal and temporal lobes may also be involved, and although the abnormality primarily affects the subcortical white matter, the cortex and the basal ganglia may also be affected [5, 32-34].

No single antineoplastic class or agent has been consistently associated with PRES, although some chemotherapeutic agents may cause direct CNS microvascular injury [35]. PRES is more likely to be encountered after high-dose multidrug cancer therapy, typically in hematopoietic malignancies [36-39]. 


\begin{tabular}{|c|c|c|c|}
\hline $\begin{array}{l}\text { Case Reports in } \\
\text { Oila: }\end{array}$ & $\begin{array}{l}\text { Case Rep Oncol 2011;4:82-87 } \\
\text { DOI: } 10.1159 / 000324581\end{array}$ & \begin{tabular}{|l} 
Published online: \\
February 16,2011
\end{tabular} & $\begin{array}{l}\text { O } 2011 \text { S. Karger AG, Basel } \\
\text { ISSN } 1662-6575 \\
\text { www.karger.com/cro }\end{array}$ \\
\hline
\end{tabular}

Gemcitabine is a nucleoside analogue antineoplastic agent structurally similar to cytarabine that is approved by the US Food and Drug Administration for the use in nonsmall cell lung, breast, ovarian, and pancreatic cancers [40]. It is unclear if gemcitabine can cross the blood-brain barrier [41]. Neurologic toxicities with gemcitabine are uncommon and include peripheral neuropathy and somnolence in 3 and $9 \%$ of patients, respectively [42]. Few data are available showing the association of PRES and gemcitabine. Gemcitabine-associated PRES was first identified in 2001 in the treatment of non-small cell carcinoma of the lung [29]. Two studies demonstrated the association of PRES and gemcitabine in gallbladder and pancreatic cancer treatment [35, 43]. This case is the first report of PRES associated with gemcitabine monotherapy in a treatment with adjuvant intent.

\section{Conclusion}

PRES is an entity not well known by neurologists and radiologists. Due to the poor knowledge of this syndrome, i.e. its cause and pathophysiology are not yet fully defined, it is sometimes not recognized. However, because of the increasing number of neuroimaging studies that have been conducted as well as of therapies that can induce PRES (which increases the number of patients treated with chemotherapy or immunosuppression), this phenomenon is becoming increasingly common.

Our report demonstrates that gemcitabine per se is associated with PRES, independent of other drugs.

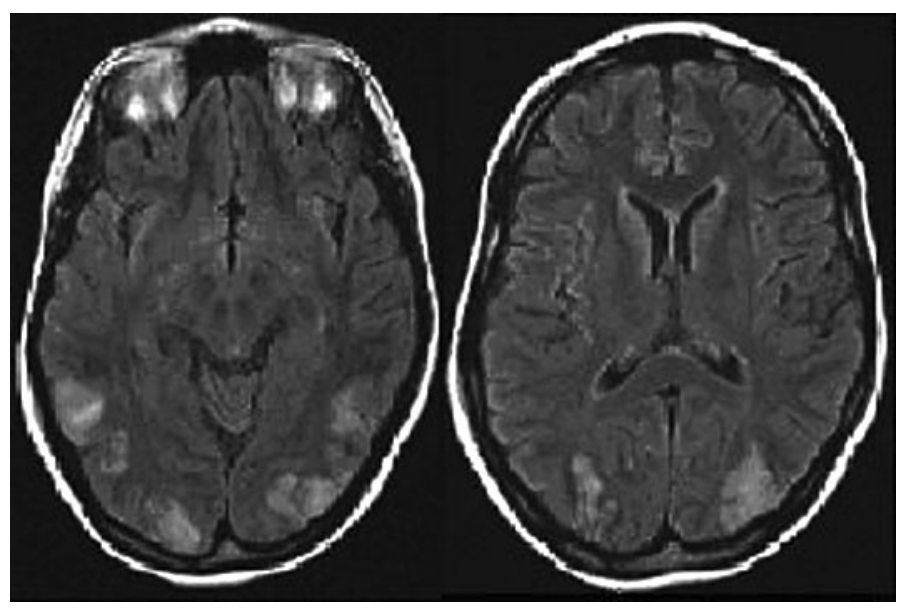

Fig. 1. Brain MRI showing the subcortical edema in the occipital and temporal lobes. 


\begin{tabular}{c|l|l|l} 
Case Reports in & $\begin{array}{l}\text { Case Rep Oncol 2011;4:82-87 } \\
\text { DOI: } 10.1159 / 000324581\end{array}$ & $\begin{array}{l}\text { Published online: } \\
\text { February 16, 2011 }\end{array}$ & $\begin{array}{l}\text { ISSN 1662-6575 } \\
\text { www.karger.com/cro }\end{array}$ \\
\hline
\end{tabular}

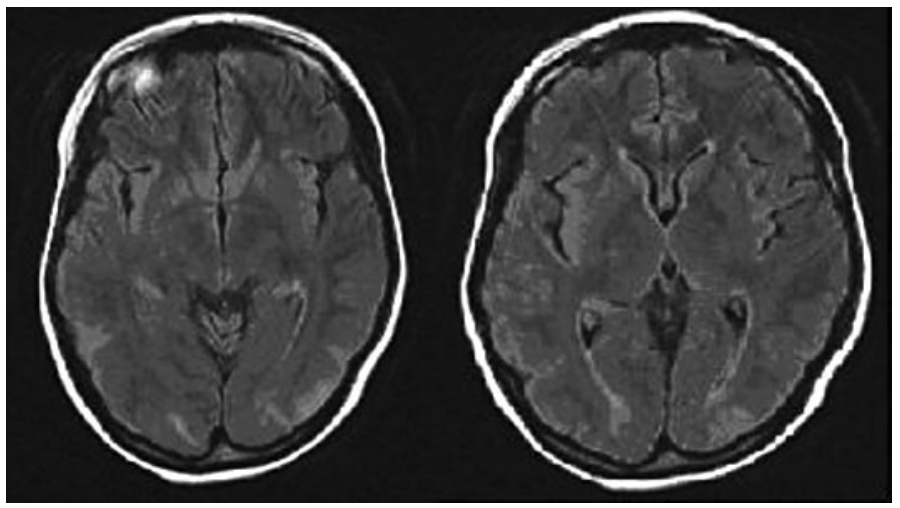

Fig. 2. Brain MRI showing a reduction of the subcortical edema.

\section{References}

1 Hinchey J, Chaves C, Appignani B, Breen J, Pao L, Wang A, Pessin MS, Lamy C, Mas JL, Caplan LR: A reversible posterior leukoencephalopathy syndrome. N Engl J Med 1996;334:494-500.

-2 Sheth RD, Riggs JE, Bodenstenier JB, Gutierrez AR, Ketonen LM, Ortiz OA: Parietal occipital edema in hypertensive encephalopathy: a pathogenic mechanism. Eur Neurol 1996;36:25-28.

- 3 Hauser RA, Lacey DM, Knight MR: Hypertensive encephalopathy: magnetic resonance imaging demonstration of reversible cortical and white matter lesions. Arch Neurol 1988;45:1078-1083.

4 Weingarten K, Barbut D, Filippi C, Zimmerman RD: Acute hypertensive encephalopathy: findings on spinecho and gradient-echo MR imaging. AJR Am J Roentgenol 1994;162:665-670.

-5 Schwartz RB, Jones KM, Kalina P, Bajakian RL, Mantello MT, Garada B, Holman BL: Hypertensive encephalopathy: findings on CT, MR imaging, and SPECT imaging in 14 cases. AJR Am J Roentgenol 1992;159:379-383.

6 Fisher M, Maister B, Jacobs R: Hypertensive encephalopathy: diffuse reversible white matter CT abnormalities. Ann Neurol 1985;18:268-270.

7 Lewis LK, Hinshaw DB Jr, Will AD, Hasso AN, Thompson JR: CT and angiographic correlation of severe neurological disease in toxemia of pregnancy. Neuroradiology 1988;30:59-64.

8 Port JD, Beauchamp NJ Jr: Reversible intracerebral pathologic entities mediated by vascular autoregulatory dysfunction. Radiographics 1998;18:253-267.

\$ Strandgaard S, Paulson OB: Cerebral autoregulation. Stroke 1984;15:413-416.

10 Nag S, Robertson DM, Dinsdale HB: Cerebral cortical changes in acute experimental hypertension: an ultrastructural study. Lab Invest 1977;36:150-161.

11 Schwartz RB, Mulkern RV, Gudbjartsson H, Jolesz F: Diffusion-weighted MR imaging in hypertensive encephalopathy: clues to pathogenesis. Am J Neuroradiol 1998;19:859-862.

12 Mukherjee P, McKinstry RC: Reversible posterior leukoencephalopathy syndrome: evaluation with diffusiontensor MR imaging. Radiology 2001;219:756-765.

13 Schaefer PW, Buonanno FS, Gonzalez RG, Schwamm LH: Diffusion-weighted imaging discriminates between cytotoxic and vasogenic edema in a patient with eclampsia. Stroke 1997;28:1082-1085. 
14 Coley SC, Porter DA, Calamante F, Chong WK, Connelly A: Quantitative MR diffusion mapping and cyclosporine-induced neurotoxicity. AJNR Am J Neuroradiol 1999;20:1507-1510.

-15 Ay H, Buonanno FS, Schaefer PW, Le DA, Wang B, Gonzalez RG, Koroshetz WJ: Posterior leukoencephalopathy without severe hypertension: utility of diffusion-weighted MRI. Neurology 1998;51:1369-1376.

16 Donaldson JO: The brain in eclampsia. Hypertens Pregnancy 1994;13:115.

17 Roberts JM, Redman CWG: Pre-eclampsia: more than pregnancy-induced hypertension. Lancet 1993;341:1447-1451; erratum 1993;342:504.

18 Schwartz RB, Feske SK, Polak JF, DeGirolami U, Iaia A, Beckner KM, Bravo SM, Klufas RA, Chai RY, Repke JT: Preeclampsia-eclampsia: clinical and neuroradiographic correlates and insights into the pathogenesis of hypertensive encephalopathy. Radiology 2000;217:371-376.

19 Colosimo C Jr, Fileni A, Moschini M, Guerrini P: CT findings in eclampsia. Neuroradiology 1985;27:313-317.

20 Naheedy MH, Biller J, Schiffer M, Azar-Kia B, Gaianopoulous J, Zarandy S: Toxemia of pregnancy: cerebral CT findings. J Comput Assist Tomogr 1985;9:497-501.

-21 Ishimori ML, Pressman BD, Wallace DJ, Weisman MH: Posterior reversible encephalopathy syndrome: another manifestation of CNS SLE? Lupus 2007;16:436-443.

22 Punaro M, Abou-Jaoude P, Cimaz R, Ranchin B: Unusual neurologic manifestations (II): posterior reversible encephalopathy syndrome (PRES) in the context of juvenile systemic lupus erythematosus. Lupus 2007;16:576579.

23 Baizabal-Carvallo JF, Barragán-Campos HM, Padilla-Aranda HJ, Alonso-Juarez M, Estañol B, Cantú-Brito C, García-Ramos G: Posterior reversible encephalopathy syndrome as a complication of acute lupus activity. Clin Neurol Neurosurg 2009;111:359-363.

24 Bartynski WS, Tan HP, Boardman JF, Shapiro R, Marsh JW: Posterior reversible encephalopathy syndrome after solid organ transplantation. AJNR Am J Neuroradiol 2008;29:924-930.

25 Hourani R, Abboud M, Hourani M, Khalifeh H, Muwakkit S: L-asparaginase-induced posterior reversible encephalopathy syndrome during acute lymphoblastic leukemia treatment in children. Neuropediatrics 2008;39:46-50.

26 Bartynski WS, Boardman JF, Zeigler ZR, Shadduck RK, Lister J: Posterior reversible encephalopathy syndrome in infection, sepsis, and shock. AJNR Am J Neuroradiol 2006;27:2179-2190.

27 Onder AM, Lopez R, Teomete U, Francoeur D, Bhatia R, Knowbi O, Hizaji R, Chandar J, Abitbol C, Zilleruelo G: Posterior reversible encephalopathy syndrome in the pediatric renal population. Pediatr Nephrol 2007;22:1921-1929.

28 Gokce M, Dogan E, Nacitarhan S, Demirpolat G: Posterior reversible encephalopathy syndrome caused by hypertensive encephalopathy and acute uremia. Neurocrit Care 2006;4:133-136.

29 Russell MT, Nassif AS, Cacayorin ED, Awwad E, Perman W, Dunphy F: Gemcitabine-associated posterior reversible encephalopathy syndrome: MR imaging and MR spectroscopy findings. Magn Reson Imaging 2001;19:129-132.

-30 Duncan R, Hadley D, Bone I, Symonds EM, Worthington BS, Rubin PC: Blindness in eclampsia: CT and MR imaging. J Neurol Neurosurg Psychiatry 1989;52:899-902.

-31 Truwit CL, Denaro CP, Lake JR, DeMarco T: MR imaging of reversible cyclosporin A-induced neurotoxicity. AJNR Am J Neuroradiol 1991;12:651-659.

32 Lamy C, Oppenheim C, Méder JF, Mas JL: Neuroimaging in posterior reversible encephalopathy syndrome. J Neuroimaging 2004;14:89-96.

-33 Sanders TG, Clayman DA, Sanchez-Ramos L, Vines FS, Russo L: Brain in eclampsia: MR imaging with clinical correlation. Radiology 1991;180:475-478.

34 De Klippel N, Sennesael J, Lamote J, Ebinger G, de Keyser J: Cyclosporin leukoencephalopathy induced by intravenous lipid solution. Lancet 1992;339:1114.

35 Rajasekhar A, George TJ Jr: Gemcitabine-induced reversible posterior leukoencephalopathy syndrome: a case report and review of literature. Oncologist 2007;12:1332-1335.

-36 Cooney MJ, Bradley WG, Symko SC, Patel ST, Groncy PK: Hypertensive encephalopathy: complication in children treated for myeloproliferative disorders - report of three cases. Radiology 2000;214:711-716.

37 Morris EB, Laningham FH, Sandlund JT, Khan RB: Posterior reversible encephalopathy syndrome in children with cancer. Pediatr Blood Cancer 2007;48:152-159.

38 Sánchez-Carpintero R, Narbona J, López de Mesa R, Arbizu J, Sierrasesúmaga L: Transient posterior encephalopathy induced by chemotherapy in children. Pediatr Neurol 2001;24:145-148.

39 Pihko H, Tyni T, Virkola K, Valanne L, Sainio K, Hovi L, Saarinen UM: Transient ischemic cerebral lesions during induction chemotherapy for acute lymphoblastic leukemia. J Pediatr 1993;123:718-724. 
40 Burris HA 3rd, Moore MJ, Andersen J, Green MR, Rothenberg ML, Modiano MR, Cripps MC, Portenoy RK, Storniolo AM, Tarassoff P, Nelson R, Dorr FA, Stephens CD, Von Hoff DD: Improvements in survival and clinical benefit with gemcitabine as first-line therapy for patients with advanced pancreas cancer: a randomized trial. J Clin Oncol 1997;15:2403-2413.

41 Plunkett W, Huang P, Xu YZ, Heinemann V, Grundewald R, Gandhi V: Gemcitabine: metabolism, mechanisms of action, and self-potentiation. Semin Oncol 1995;22(suppl 11):3-10.

42 Gemzar_ (gemcitabine $\mathrm{HCl}$ for injection) [package insert]. Indianapolis, Eli Lilly and Company, 2006.

-43 Kwon EJ, Kim SW, Kim KK, Seo HS, Kim do Y: A case of gemcitabine and cisplatin associated posterior reversible encephalopathy syndrome. Cancer Res Treat 2009;41:53-55. 